\title{
Mineral, Vitamin and Phytochemical Content of the Tigernut
}

\author{
Ani Abosede Oluwakemi ${ }^{*}$, Adelere Folake Irewunmi, Sholotan Kazeem Joshua, \\ Nwaemeke David Iweunor
}

Science Laboratory Technology, Ogun State Institute of Technology, Igbesa, Nigeria

\section{Email address:}

edunkemy@gmail.com (A. A. Oluwakemi), adelerefolake@gmail.com (A. F. Irewunmi), abdulrasheed4kc@yahoo.com (S. K. Joshua), dnwaemeke@gmail.com (N. D. Iweunor)

${ }^{*}$ Corresponding author

\section{To cite this article:}

Ani Abosede Oluwakemi, Adelere Folake Irewunmi, Sholotan Kazeem Joshua, Nwaemeke David Iweunor. Mineral, Vitamin and Phytochemical Content of the Tigernut. World Journal of Applied Chemistry. Vol. 6, No. 3, 2021, pp. 36-40.

doi: $10.11648 /$ j.wjac.20210603.12

Received: May 21, 2021; Accepted: June 11, 2021; Published: August 11, 2021

\begin{abstract}
Tigernut, or Cyperus esculentus L, is a tuber that grows and is frequently consumed in West Africa. Tigernut tuber is highly nutritive with high starch, glucose and proteins contents. It's high in minerals (including phosphorus and potassium), as well as vitamins $\mathrm{C}, \mathrm{D}$, and $\mathrm{B}_{1}$, which all assist to improve antioxidant activity. It can be consumed raw or dried and combined with roasted peanuts. The minerals, vitamins and phytochemical contents of tigernut were analyzed using accepted methods after the minerals value of the plant tubers were carefully pounded and grounded to paste. The presence of Tannin, Terpenes, Phenol, and Steroids were discovered as a result of phytochemical research in trace and in moderate concentration. Tigernut was found to contain $0.5305 \%$ phytochemicals. Phenol had a concentration of $0.236 \%$, Saponin had a concentration of $0.167 \%$, Glycosides had a concentration of $0.124 \%$, Steroids had a concentration of $0.0028 \%$, Tannin had a concentration of $0.0018 \%$, and Terpenes had a concentration of $0.0017 \%$. Also, the minerals assay revealed the presence of presence of calcium $\left(\mathrm{Ca}^{2+}\right)$, potassium $\left(\mathrm{K}^{+}\right)$, copper $\left(\mathrm{Cu}^{2+}\right)$, iron $\left(\mathrm{Fe}^{2+}\right)$, magnesium $\left(\mathrm{Mg}^{2+}\right)$, manganese $\left(\mathrm{Mn}^{2+}\right)$ and phosphorous $\left(\mathrm{P}^{+}\right)$in the tigernut tuber sample. Highest mineral element found was potassium $\left(\mathrm{K}^{+}\right)$and least was zinc with values of $4478.76 \mathrm{mg} / \mathrm{kg}$ and 0.589 $\mathrm{mg} / \mathrm{kg}$ respectively. Tigernut tubers also contains high levels of vitamin $\mathrm{C}, \mathrm{B}_{1}$, and $\mathrm{D}$. Vitamin $\mathrm{D}$ was present in higher concentrations in $(\mu \mathrm{g} / 100 \mathrm{~g})$ of $(22.79 \mu \mathrm{g} / 100 \mathrm{~g})$ followed by vitamin $\mathrm{C}(5.76 \mathrm{mg} / 100 \mathrm{~g})$ and vitamin $\mathrm{B}_{1}(2.38 \mathrm{mg} / 100 \mathrm{~g})$. The result showed that tigernut tuber contain appreciable number of minerals, vitamins and low level of phytochemicals and could contribute to the recommended dietary allowance of the body.
\end{abstract}

Keywords: Tigernut, Minerals, Phytochemical, Vitamin C, Vitamin D, Vitamin B $_{1}$

\section{Introduction}

Cyperus esculentus is a monocotyledonous plant that belongs to the Cyperaceae family [17], which contains about 4000 species.

Tiger nut is a perennial grass that thrives in moist regions and is frequently found as a weed, particularly on fields where vegetables are grown 17]. The plant grows to a height of 1-3 $\mathrm{ft}$ and pollination occurs by the wind. It grows mainly in the tropical and warm temperate regions of the world. Yellow nuts edge, chufa, flats edge, rush nut, water grass, earth almond, northern nut grass, and nut grass are some of its other names. Tigernuts grow near rivers and are commonly produced on a modest scale by indigenous farmers in Nigeria's northern areas.

In Nigeria, it is known by many names such as "aya," "akiawusa," and "ofio.". Tigernut is said to be steady and advantageous to the heart, blood circulation, and thrombosis.

Because of its high soluble glucose content, it aids in cancer prevention.

It has also been discovered to aid in the prevention of colon cancer. The nut is rich in mineral (phosphorus, 
potassium) and vitamins. Tigernut is beneficial to diabetics and aids in weight loss [16]. Tigernut tubers are rich in protein, vitamins, minerals, and other beneficial plant compounds.

Until you eat or roast tigernuts, their antioxidant content will rise and the body will absorb the nutrients. Tigernuts can contain enzymes like catalases, lipases, and amylases, which aid in the digestion of foods in the gut, reducing gas, indigestion, and diarrhea. Tigernuts are high in insoluble fiber, which can help you avoid constipation and maintain a healthy digestive system [6].

To prevent painful gas or bloating, gradually incorporate them into your diet. Tigernuts are high in fiber and arginine, two nutrients that can help lower blood sugar [6].

Minerals and vitamins are classified as micronutrients because they are needed by the body in minute amounts (milligrams or micrograms) but are necessary for the production of enzymes, hormones, and other substances required for proper growth and development [4]. Microminerals are required when the amount needed by the human body every day is less than $100 \mathrm{mg}$ and macro-minerals are required when the amount needed is greater than $100 \mathrm{mg}$. Vitamins in tigernut on the other hand, are involved in cell formation, tissue overhaul, and other vital processes that make up the body's metabolic system. They can be fatsoluble or water-soluble [4].

Collagen, hormones, and neurotransmitters all require vitamin $\mathrm{C}$ to function properly.

$100 \mathrm{~g}$ of tigernuts could also meet 77 percent of teenage vitamin $\mathrm{C}$ requirements, 69 percent of adult vitamin $\mathrm{C}$ requirements, and 52 percent of vitamin $\mathrm{C}$ requirements for expectant moms [9].

In addition, tigernuts high vitamin $\mathrm{C}$ content will help to make iron more soluble and available.

Vitamin $\mathrm{C}$ is an antioxidant that can help you avoid heart disease and cancer. Heart-healthy fats abound in tigernuts. They can improve blood circulation, vein and artery flexibility, lowering your risk of heart disease. By fighting infections, including those caused by antibiotic-resistant bacteria, tigernuts can help to build a stronger immune system [9].

Tigernut is thought to have certain medicinal properties for increasing libido. In Ayuvedic medicine, they are used as aphrodisiacs. In certain parts of the world, tigernuts are used as a natural aphrodisiac. Tigernuts can be added to the diet in several respects. They can be eaten raw or fried, on their own or in combination with other foods, dairyfree products, or baked goods. They are high in nutrients, help with digestion, and can help protect you from infections and diseases like diabetes and heart disease. Tigernut milk consumption has not been linked to any form of allergy. Tigernut was also high in myristic, oleic, and linoleic acids [16]

The aim of this research is to determine the phytochemical composition of the tuber as well as the mineral and vitamin contents of Tigernut.

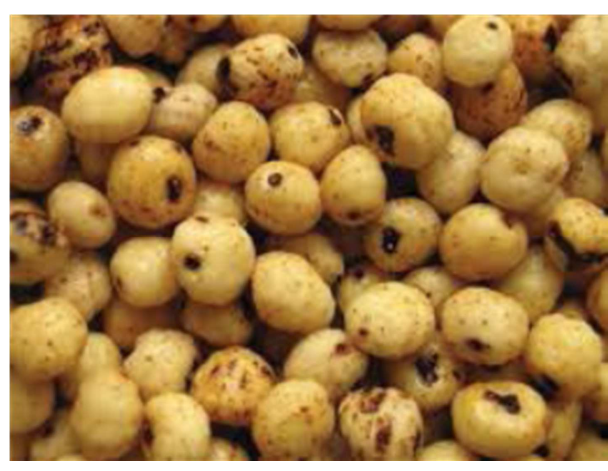

Figure 1. Tigernut (yellow).

\section{Materials and Procedures}

\subsection{Collection of Samples}

A technician from the Department of Science and Technology Igbesa, Ogun State, Nigeria, verified fresh raw tigernuts (approximately $10 \mathrm{~kg}$ ) collected from a local market in Alaba Lagos, Lagos State, Nigeria.

\subsection{Sample Preparation}

Fresh tigernuts were visually inspected, with those that were found to be defective being removed and discarded manually.

Only mature and stable tigernut tubers were chosen as a result. It was weighed to $500 \mathrm{~g}$, cleaned thoroughly in two changes of clean water, and drained before being used in the analysis. The weighted samples were mashed with a mortar and pestle until they achieved a fine consistency, then refrigerated for further examination.

\subsection{Phytochemical Analyses of Tigernuts}

The presence and absence of saponins, alkaloids, flavonoids, cyanogenic glycosides, tannins, glycosides, and sterols were determined by a phytochemical test using Harbone's method (1984). The result of the phytochemical analyses was determined in percent.

\subsection{Minerals Analyses}

Flame photometry was used to determine the potassium and sodium content of the samples, while the phosphorus concentration was assessed using the technique [2].

The elemental contents of other elements $(\mathrm{Na}, \mathrm{Ca}, \mathrm{Mg}, \mathrm{Cu}$, $\mathrm{Mn}$, Nikel, Lead, Chromium, and Fe) were determined using an Atomic Absorption Spectrometer. Absorption Spectrophotometer [3].

\subsection{Vitamins $C, D$ and $B_{1}$}

The spectrophotometric method described by the [2]. Was used to determine the vitamin D content of the sample.

Ascorbic acid (Vitamin C): Vitamin C content of the sample was determined by spectrometric method coupled with DNPH procedures 12]. While vitamin $\mathrm{B}_{1}$ were analyzed using UV spectroscopy. 


\section{Results}

\subsection{Phytochemical Analyses of Tigernuts}

The phytochemical analysis of fresh tigernuts is presented in Table 1 as a percentage.

Tigernut was found to contain 0.5305 percent phytochemicals.

Phenol had a concentration of 0.236 percent, Saponin had a concentration of 0.167 percent, Glycosides had a concentration of 0.124 percent, Steroids had a concentration of 0.0028 percent, Tannin had a concentration of 0.0018 percent, and Terpenes had a concentration of 0.0017 percent.

Table 1. Phytochemical composition of tigernut tuber (\%).

\begin{tabular}{ll}
\hline Components & Values \% \\
\hline Tannin & 0013 \\
Saponnin & 0.167 \\
Phenol & 0.236 \\
Steroids & 0.0028 \\
Glycosides & 0.124 \\
Terpenes & 0.0017 \\
\hline
\end{tabular}

\subsection{Minerals Analysis of Tigernuts}

The mineral composition of the fresh tigernuts shown in Table 2 has high minerals element in potassium (K), phosphorus $(\mathrm{P})$, sodium $(\mathrm{Na})$, calcium $(\mathrm{Ca})$ and iron $(\mathrm{Fe})$, as the major constituents of tigernuts though the amount of Magnessium, Manganese, Cadmium and zinc present are reduced.

Table 2. Minerals composition of tigernut tuber ( $\mathrm{mg} / \mathrm{kg})$.

\begin{tabular}{ll}
\hline Mineral element & Concentration $(\mathbf{m g} / \mathbf{k g})$ \\
\hline Zinc & 0.589 \\
Cadmium & 1.653 \\
Nickel & 0 \\
Iron & 45.617 \\
Lead & 0 \\
Chromium & 0 \\
Copper & 1.233 \\
Calcium & 1.776 \\
Magnesium & 13.985 \\
Manganese & 8.151 \\
Sodium & 956.38 \\
Potassium & 4478.76 \\
Phosphorous & 33.97 \\
\hline
\end{tabular}

\subsection{Vitamin Analysis of Tigernuts}

Table 3 shows the results of the vitamins $C, D$ and $B_{1}$. Vitamin D is measure in microgram per $100 \mathrm{~g}$, while vitamin $\mathrm{C}$ and $\mathrm{B}_{1}$ are measured in milligram.

Table 3. Vitamin composition of tigernut tuber $(\mathrm{mg} / 100 \mathrm{~g})$ and $(\mu \mathrm{g} / 100 \mathrm{~g})$.

\begin{tabular}{lll}
\hline Vitamins & Concentration in $(\mathbf{m g} / \mathbf{1 0 0 g})$ & Concentration in $(\boldsymbol{\mu g} / \mathbf{1 0 0 g})$ \\
\hline Vitamin C & 5.76 & 22.79 \\
Vitamin D & & \\
Vitamin $B_{1}$ & 2.38 & \\
\hline
\end{tabular}

\section{Discussion}

As a result of phytochemical study, Phenol, Saponnin, Glycosides, Steroids, Tannin, and Terpenes are listed in decreasing order in Table 1.

Because of its interaction with chemicals such as sex hormones, steroids are of great importance and interest in pharmacy. Tannins are astringent, which means they help wounds heal faster and prevent deterioration [10].

Glycosides tend to alter biological activity by assisting in the strengthening of heart muscle contractions. Saponnin acts as an anticancer agent [17]. Reducing the mutagenic activity of a variety of mutagens and inhibiting the growth of fungi, yeasts, bacteria, and viruses.

Antimicrobial, analgesic, anti-inflammatory, antioxidant, anti-convulsant, anti-cancer, anesthetic, antiseptic, and disinfecticides, properties have also been discovered in phenol derivatives [11].

Terpene is an anticancer, antimicrobial, antifungal, antiviral, ant hyperglycemic, analgesic, anti-inflammatory, and antiparasitic compound that is used to improve skin penetration and avoid inflammatory diseases [8].

The phytochemicals obtained from the tuber of tigernuts contain several biologically active compounds that could be used as a source of herbal medicine vegetable drugs.

The fresh tigernut in Table 2 has higher potassium $(\mathrm{K})$, phosphorus $(\mathrm{P})$, sodium $(\mathrm{Na})$, calcium $(\mathrm{Ca})$, iron $(\mathrm{Fe})$, phosphorous $(\mathrm{P})$, and magnesium, according to the current report $(\mathrm{Mg})$, Manganese $(\mathrm{Mn})$, Cadium $(\mathrm{Cd})$, zinc $(\mathrm{Zn})$, and copper $(\mathrm{Cu})$ content are all lower, with values of 4478.76 $\mathrm{mg} / \mathrm{kg}, 956.38 \mathrm{mg} / \mathrm{kg}, 61.776 \mathrm{mg} / \mathrm{kg}, 45.617 \mathrm{mg} / \mathrm{kg}, 33.97$ $\mathrm{mg} / \mathrm{kg}, 13.9985 \mathrm{mg} / \mathrm{kg}, 8.151 \mathrm{mg} / \mathrm{kg}, 1.653 \mathrm{mg} / \mathrm{kg}$, and 0.589 $\mathrm{mg} / \mathrm{kg}$, respectively. Essential minerals like $\mathrm{Na}, \mathrm{Ca}$, and $\mathrm{K}$ are found to be comparable to published findings [6].

Phosphorus enhances fast release of energy in the body and can combine with calcium for bone and teeth growth. Tigernuts have a low calcium and sodium content. Recent blood pressure studies have shown that a diet high in potassium and magnesium but low in sodium can lower blood pressure within days of starting the diet [10]. Potassium is a major cation in intracellular fluid and aids nerve impulse transmission.

Also, tigernuts' high potassium to low sodium ratio can be critical in diet formulations for patients with high blood pressure and edema [15].

Tigernuts are high in protective nutrients such as zinc, copper, iron, vitamin C, and vitamin D.

Zinc is found in hormones and approximately 100 different enzymes.

Zinc is required for several metabolic reactions and may play a role in the metabolism of alcohol, immunity, sexual growth, and reproduction [15].

Tigernuts have a high iron content, which can help to avoid anemia. Hemoglobin and other essential compounds used in respiration, immune function, and cognitive development include $\mathrm{Fe}$ as a functional component. Tigernuts' Fe content (100 g) may be sufficient to meet 
children's daily minimum needs (approximately 67-68 percent). Tigernuts could meet the daily iron needs of 27-64 percent of adolescents and adults, as well as 18-49 percent of pregnant mothers [15].

Vitamins are micronutrients that have protective functions in the body and must be acquired via food. Vitamin D, also known as the sunshine vitamin, was present in high concentrations in the tuber of Cyperus esculentus $(22.79 \mu \mathrm{g}$ $/ 100 \mathrm{~g})$. Vitamin analysis revealed that the tubers of Cyperus esculentus is high in vitamins $\mathrm{D}$ and $\mathrm{B}_{1}$, and $\mathrm{C}$, all of which play important roles. Increased intestinal uptake of phosphate, magnesium, and calcium, as well as a variety of other biological effects, are all attributed to vitamin D [1].

Vitamin act as co-enzymes in macronutrient metabolism. Anti-beriberi vitamin $B_{1}$ is also known as vitamin. Vitamins are micronutrients that have protective functions in the body and must be acquired via food [13]. Increased intestinal uptake of phosphate, magnesium, and calcium, as well as a variety of other biological effects, are all attributed to vitamin $\mathrm{D}$ [1]. When eaten in sufficient amounts, the tested plant samples are good sources of B and D complex and can be used to maintain good health in humans and animals. The importance of vitamins in maintaining good health cannot be over emphasized and these residues can represent another source for vital vitamins such as vitamin $C$, vitamin $B_{1}$ and D. If children aged 4 to 9 years old eat $100 \mathrm{~g}$ of tigernuts per day, the vitamin $\mathrm{C}$ content may be sufficient, providing 88100 percent of their recommended dietary intake (16). Vitamin $\mathrm{C}$ is needed for the production of collagen, hormones, and neurotransmitters. $100 \mathrm{~g}$ of tigernuts could also satisfy 77 percent of adolescent vitamin $C$ needs, 69 percent of adult vitamin $\mathrm{C}$ needs, and 52 percent of pregnant mothers' vitamin $\mathrm{C}$ needs [9].

Furthermore, tigernuts' high vitamin $\mathrm{C}$ content can make them soluble, allowing the iron content to produce more Vitamin $\mathrm{C}$ as antioxidants, which are essential in the prevention of coronary artery disease and cancer [15]. Thiamine $\left(B_{1}\right)$ vitamins play an important role in energy metabolism. Vitamin D is also important for bone and muscle health [14].

\section{Conclusion}

It is noteworthy that tigernuts contain all the phytochemicals examined. High in micronutrients and low in antinutrients shows the point that they have an effect on the recommended dietary intake.

Essential elements such as $\mathrm{Na}, \mathrm{K}, \mathrm{Mg}, \mathrm{Mn}, \mathrm{Ca}, \mathrm{Fe}$, and $\mathrm{Zn}$ were discovered in significant quantities.

Tigernut exceeded phytochemicals, mineral composition, and vitamins found in certain other edible nuts and tubers, indicating that it can be a valuable source of nutrients and phytochemicals. Vitamins such as $\mathrm{B}_{1}, \mathrm{D}$, and $\mathrm{C}$ were also present.

There is a need for increased use and understanding of the health benefits of the underutilized tigernuts, given their nutritive and health benefits.
Above all, it is hoped that including tigernut in one's diet would help to 'mop-up' free radicals and reduce the risk of cardiovascular and other age-related diseases.

\section{References}

[1] Achikanu, C. E., Ani, O. N., and Akpata, E. I. (2020). Proximate, vitamin and phytochemical composition of Cucumis metuliferus seed. Steroids, 2, 0-158.

[2] A. O. A. C. 2005. $20^{\text {th }}$ edition published by association of Official Analytical Chemists Anligton, Virginia, USA.

[3] Arafat, S. M., Gaafar, A. M., Basuny, A. M., and Nassef, S. L. (2009). Chufa tubers (Cyperus esculentus L.): As a new source of food. World Applied Sciences Journal, 7 (2), 151-156.

[4] Anyalogbu E. A., and Ezejiofor T. I. N., 2017. Effect of processing on Antinutrients contents of African Elemi (Canarium schweinfurthii) And African Walnut (Plukenetia conophora) Consumed As traditional snacks in Nigeria. Int $1 \mathrm{~J}$. of Scientific and Technol. Res. 6 (7). 383-391.

[5] Belewu, M. A., and Belewu, K. Y. (2007). Comparative physico-chemical evaluation of tigernut, soybean and coconut milk sources. International Journal of Agriculture and Biology, 5 (785), e787.

[6] Bilikis, A., and Olanrewaju, A. (2015). Chemical compositions, antioxidant capacity of tigernut (Cyperus esculentus) and potential health benefits. European Scientific Journal.

[7] Chukwuma, E. R., Obioma, N., and Christopher, O. I. (2010). The phytochemical composition and some biochemical effects of Nigerian tigernut (Cyperus esculentus L.) tuber. Pakistan Journal of Nutrition, 9 (7), 709-715.

[8] Cox-Georgian, D., Ramadoss, N., Dona, C., and Basu, C. (2019). Therapeutic and medicinal uses of terpenes. In Medicinal Plants (pp. 333-359). Springer, Cham.

[9] Ezeh, O., Gordon, M. H., and Niranjan, K. (2014). Tiger nut oil (Cyperus esculentus L.): A review of its composition and physico-chemical properties. European journal of lipid science and technolgy, 116 (7), 783-794.

[10] Imam, T. S., Aliyu, F. G., and Umar, H. F. (2013). Preliminary phytochemical screening, elemental and proximate composition of two varieties of Cyperus esculentus (Tiger nut). Nigerian Journal of Basic and Applied Sciences, 21 (4), 247-251.

[11] Kumar, A., and Mishra, A. K. (2018). Biological importance of phenol derivatives as potent bioactive compound: a review. Letters in Organic Chemistry, 15 (4), 251-264.

[12] Khan, M. R., Rahman, M. M., Islam, M. S., and Begum, S. A. (2006). A simple UV-spectrophotometric method for the determination of vitamin $\mathrm{C}$ content in various fruits and vegetables at Sylhet area in Bangladesh. J. Biol. Sci, 6 (2), 388-392.

[13] Koirala, N., Dhakal, C., Munankarmi, N. N., Ali, S. W., Hameed, A., Martins, N. and Salehi, B. (2020). Vitex negundo Linn.: phytochemical composition, nutritional analysis, and antioxidant and antimicrobial activity. 
[14] Onyegeme-Okerenta, B. M., Nwosu, T., and Wegwu, M. O. (2017). Proximate and phytochemical composition of leaf extract of Senna alata (L) Roxb. Journal of Pharmacognosy and Phytochemistry, 6 (2), 320-326.

[15] Cellular and Molecular Biology, 66 (4), 1-7.

[16] Stroud, M. L., Stilgoe, S., Stott, V. E., Alhabian, O., and Salman, K. (2008). Vitamin D: a review. Australian Journal of General Practice, 37 (12), 1002.
[17] Suleiman, M. S., Olajide, J. E., Omale, J. A., Abbah, O. C., and Ejembi, D. O. (2018). Proximate composition, mineral and some vitamin contents of tigernut (Cyperus esculentus). Clinical Investigation, 8 (4), 161-165.

[18] Wayah, S. B., and Shehu, S. (2013). Assessment of the Nutritional and Anti-nutritional Components of Tiger nut Residues. International Journal of Scientific Research, 4 (6), 342- 344.

[19] Yildirim, I. and Kutlu, T. (2015). Anticancer agents: saponin and tannin. 